\title{
4-2 情緒工学とその応用
}

\section{1. 情緒工学とは}

情緒工学 (Emotion Technology) という言葉は, 本 学会会長の大島正光が最初に提案したものであり ${ }^{1)}$, 当 初は情緒発生機序のメカニズムの解明, 情緒コントロー ル, 情緒と物理的要素との関連性など, 多義にわたって 解説し問題点を指摘した。これに刺激されて研究を開始 し今日にいたったのが本論文の経緯であり, 主として大 島の指摘する情緒と物理的要素との関連性に焦点をあて た研究である.

情緒工学に着手したのは昭和 46 年であったが，当時， 経済界は高度成長の時期であり，物質的満足の時代の次 には必ず精神的満足や充足を求める時代が到来するはず であり，情緒や感情を主軸とする生活が基本となるであ ろうと推察した. 当時としては, てのような内容の話を するには少し早すぎた感がしないではなかったが，少し 経って TQC がよりいっそう以ばれ，マーケットイン思 想が強調されるにいたった情況のなかで，研究が進んで いった.

本論文で扱う情緒工学とは，“人間が物理的対象につ いて心のなかで抱く感情やイメージなどの心理的要因 を, 具体的な次元で物理的なデザイン要素として表現あ るいは実現する翻訳機能に関する研究分野”であり，人 間をとりまく物理的要因と人間の感情や情緒といった心 理的要因を結びつけ尺度化する研究分野であると定義す る.たとえば, 狭い空間に閉じ込められると人間は圧迫

\section{長町三生}

感をもち, クラシック音楽を楽しみたいときには部屋の 照明を暗くするといった事柄は，心理学ではよく知られ ている事実であるが，ではクラシックとポップスとでは 照度レベル (物理的要素) でどう違えればよいのかとい った, 物理的要素の詳細な点ではあまり論究されなか った. 人間工学が工学などの自然科学と心理学などの社 会科学の間にたつ学際科学であるならば,もう少し工学 的分野からみた心理的情報之数值化や尺度化が行われる ならば，感情や情緒を充足する生活空間を実現すること もできるし，情緒コントロールを医薬を使わないで物理 的あるいは環境的に実施することも可能となるはずであ ろ.

\section{2. 情緒工学の研究の流れ}

情緒工学の研究対象は何でもよかったのであるが，当 時, 住宅やホテルなどの壁紙製造業と接触があったてと から, 人間工学実験室のなかに小さな空間をつくって, 色彩空間の情緒的効果について研究を開始した．色彩調 節や色彩心理学の世界でいわれていた事実が続々と明ら かになっていったが，乙の昭和 46 年当時, 林式数量化 理論による数值分析でてれらをまとめることがうまくで きることに気づいた2).

これに力を得て，いよいよ HLS (Human Living System）の開発に着手するととになった²). 実験室の壁 に各種の壁紙を貼りつけて，そのなかに長時間いる被験 者から色彩から感じられる情緒の計測に入ったのだが,

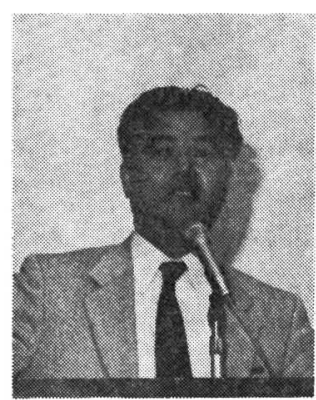

著者の略歴 : 長町三生 (広島大学工学部) 昭和33年, 広島大学教育学部心理学科 を卒業, 続いて大学院に進学, 38 年に大学院博士課程を修了し文学博士の称号を授与. 当時は学習心理学, 特に学習過程の数学モデル構築の研究に従事. 工学部助手, 助教 授, 昭和 53 年より教授となり，人間工学わょび労務管理の教育・研究を担当する．人 間工学の分野では, 自動車のデザイン・交通工学・生産ラインの職務再設計・安全管 理・ロボティックスなどの研究に従事し, 最近, 情報工学分野への移籍に伴い, 知識 工学および知的 CAI に研究が集中している. 
1 試行で数万円も経費が必要となり，てれは中止せざる をえなかった，そてで実物の空間に代わるものをという ことで, 実験室の寸法と合わせて縮尺した模型をきれい に製作し，一面だけから被験者がのぞき見るととにし， あとの天井・床・壁などを実験計画に準じて変更する方 法を採用し, 実物と模型の情緒間に 0.9 在超える相関係 数を得たので,ての方法に切りかえた. しかし,てれも 1 人の被験者しか扱えないという不便さがあって, 模型の 内側の写真を撮影し，それをスクリーンに写して10〜15 名の被験者を一度に実験するととを考元，乙の方法と実 物との相関係数がやはり 0.9 をいずれも超えるととが判 明し，最終的にスライド方式を採用することに決めた。 てうして, 室内インテリア（ここでは天井・壁・床の色 相・彩度・明度の三要素) の物理的要素々心理的情緒々 の関係を尺度化し，インテリアデザインに活用すること を考元，実験と分析を続けだ3．乙れは後に装飾業界に 導入するように応用開発を行い, HLS の名で売れてい ったのである. ての研究の方式は, 広島大学まで来校さ れた奈良女子大学住居学研究室（梁瀬度子教授）にすべ てを教授し，建築学会の人間工学的分野にも営々と受け 継がれている.

\section{3. 情緒工学の研究方法とその応用例}

\section{3-1. SD 尺度の決定}

まず情緒を適切に表現する形容詞の探求から始まる. たとえば室内インテリアの情緒を研究するためには，室 内空間のイメージに合う形容詞が何であるかを把握しな ければならないし、Osgood の SD 法を用いるのであれ ば，そのための意味空間も把握しておく必要がある.わ れわれの場合, 建築雑誌儿揭載されている用語を遂一調 查して 500 個の対語を用意し，それを因子分析にかけて 因子構造を把握した。 また, 後述する HULIS では, 建 設会社の空口で顧客との対話を記録し，そてで用いられ る用語の対語を因子分析にかけている.

てれまでの経験では，SD 法による分析のために形容 詞の対語を用意するわけであるが，学生たちや女性の被 験者の因子構造は明確なものにならないてとが多く，特 に後者の因子構造は因子数が非常に多くなるという経験 がある。したがって，できるだけデザイナーという専門 家を被験者として,イメージの情緒空間を把握すること にしている.

前述の 500 対語では, 実用的には多すぎるし, 意味が 重複しているものも多いので, 相関係数や因子構造を加
味しながら適切な数に縮小する．どの程度に少なくする かは研究対象や研究目的に関連するが、HULIS では実 用性が重視されているので 227 対語にした.

ここまでの作業をするには，下記のような手順に従え ばよい。

(1) 研究対象と目的を明確にする。

(2) その分野に直接関係する形容詞を収集する.

（3）その分野のイメージの対象（たとえばインテリア など）をスライドに撮影し，数十枚のスライドを作 成する。

（4）適切な被験者を決めて，スライドを 1 枚ずつ見せ ながら，SD 法に基ついて形容詞の評価尺度に自分 が感じているイメージの程度を記録させる．普通 5 段階ないし 7 段階尺度が用いられるが， 5 段階尺度 で十分である。

（5）電子計算機によって，得られたデータの因子分析 を行い，形容詞の意味空間を把握する.イメージを 対象としているのであるから，数少ない因子数にな らないてともあるが， $5 \sim 6$ 個の因子数で累積寄与 率が高くならないときには, スライドの映像, 形容 詞，被験者のチェックをしたほうがよい，

（6）こてで，形容詞の数を少なくする．各因子の意味 構造を残しながら，相関係数の高い形容詞のなかか らいくつかを抜き，適当な数の形容詞にする.

\section{3-2. デザイン要素の決定と数量化分析}

次に，数量化理論にかけられるように，またどんな評 価をしたいかを考えながら，物理的なデザイン要素を決 定する.われわれは通常, 数量化理論 I 類ないしII類を 多く用いており，ての場合，外的基準は形容詞である. たとえば, 室内デザインでいえば, “明るい”部屋とい うイメージにどんなデザイン要素が大きく寄与するかを 考えるとすれば, 室内面積, 天井高, 空の面積・数・ ス タイル, 照明のスタイル・数・照度, 壁・天井・床の色 彩などを, 評価尺度化して，てれから研究しようとする 対象（こてでは室内インテリア）を物理的に数值化でき るようにしておく。

次に，たとえば室内インテリアであれば，上記の物理 的デザイン要素が網羅できるように配慮して，スライド に盛り込んで作成する．てのスライドを見せながら，前 述の最終的に決定した形容詞の評価尺度でイメージを決 定させる.

スライドが実物と異なるのではないかと心配する向き もあると思われるが，てれまでの研究では実物と 0.9 以 上の高い相関があり，全然心配はない。ただし色彩につ 
いては，現実の色と現像した後の色彩とが同一かどうか について十分に検討をしておく必要がある。なお，スラ イド映写に関して, 被験者が疲れないように, また呈示 順序効果が現れないようになどの, 実験計画法に基づい た実験になるように配虑すべきである.

目的によってどの数量化理論の分析方法を採用するか が決まる. われわれの場合 I IV 類まで使用するが, 主 としてI類ないしIII類を用いる. この場合, 外的基準を 情緒としての形容詞にするので，たとえば“明るい”と いうイメージに空の面積や空の数などがどれほど影響力 をもっているかが把握できる，てうして，期待すべきイ メージに対する貢献要因が判明するので，それらを用意 すれば，逆に望むイメージを物理的に実現できるととに なる．情緒工学を, 情緒やイメージを物理的デザイン要 素に翻訳する仕組みの研究手法であるといったのは, こ のような理由からである.

\section{3-3. いくつかの応用例}

住宅もしくは室内インテリアについては後に詳述する ので, その研究までに行ったいくつかの事例について述 べておく．ほとんどは企業との研究であり，公表できな い内容のものである.

\section{（1）ソファの情緒工学}

ソファも，他の家具などと同じく，イメージによって 作用を受け，それが販売量を左右する要因となる.ソフ アが与える心理的イメージを明らかにすれば，なぜ好ま れ,なぜ購入されるか, 逆になぜ特定のソファは売れな いのかの原因がつかめるととになる，日本でもトップク ラスのソファメーカーからの依頼により, ソファの情緒 工学的研究を行った.

このケースでは, ソファの物理的デザイン要素を色彩 も含めて抽出した．また，てれらの要素に並へて販売実 績のデータを追加した。被験者は $20 \sim 60$ 歳のすへてのの 年齢を含めた男女あわせた人たちであり，いくつかの凰 別に分析を行った.

その結果, ベストセラーやかなりの販売実績をもつソ ファと，開発したが販売がほとんど伸びず廃棄商品にな ったものなどの間に, イメージの差が非常に大きいとと がわかり，しかもてれらの差を決定的にするデザイン要 素が判明したのである. 特に開発デザイナーが進んだデ ザイン感覚で開発したものが，良いデザインとわかって いても必ずしも販売実績に結びつかない原因がはっきり したのである.

現在は, 乙の情緒工学的研究結果がマニュアル化さ れ, 開発デザイナーが開発スペックを書き上げたとてろ
で, 情緒工学的開発マニュアルをチェックするととにな っている.

\section{（2）技術者とデザイナーの共通翻訳吾語}

デザイナーは特異なフィーリングをもち，それを独特 の言葉で表現する.他方，エンジニアは考え方が具体的 であり即物的である．具体的な商品を開発する際に，開 発技術者とデザイナーとが共同作業に入るととになる が，乙の場合それぞれが抱くフィーリングや用いる言葉 が異なるために，共通概念にいたるために時間がかかる ことになる.

そてで, 良い商品を開発するために, 特に消費者の情 緒重視の商品を開発するために，そして開発期間を短縮 するために，開発技術者とデザイナーの共通言語を開発 することになり，それに情緒工学手法が応用されたので ある. 詳述することができないのだが，たとえばデザイ ナーがある特定のフィーリングをもち，それを次の新規 開発デザインにしたい場合に，開発会議でそれを発表す るが，その際に使用されるデザイナー用語が翻訳、ニュ アルによって具体的に開発技術者に理解できるようにな っている.

現在，てれは特定の企業で実用に供されている.

（3）コーヒーカップの研究

これは奈良女子大学住居学研究室で実施されたもので あり, コーヒーカップのデザイン要素を抽出し，それを スライドで表現し, 女子大学生を被験者として SD 法で 評価させた4).

若い人たちのイメージという限定されたものである が, 若い人たちをターゲットとしたコーヒーカップのデ ザイン開発には十分力をもっている結果をだしている. ここでは, カップ自体のデザインスタイル，カップ表面 の図柄と色彩, 柄のスタイル，その他が物理的デザイン 要素となっている. “若い 2 人で飲みたいとき”のカッ プとか, “ひとりで静かに 飲みたいとき”のカップなど が，明確に指定できる。

\section{（4）照明の情緒工学的研究}

照度や照明の色などについての心理学的研究は多いけ れども，具体的情緒を実現するためのマニュアル的なも のは存在しなかった.

そてで, 照明機器メーカーとの共同研究によって, て れまで常識的にいわれていたものも含めて, 特定の室内 雾囲気を醇しだすととに照明を使うマニュアル開発に着 手したのである5 ${ }^{5}$.

室内照明機器が取り換えられ，かつ照度も自由にコン トロールできるようにしたモデルルームで，その企業の 照明デザイナーを被験者として，照明方法の違いによる 


\begin{tabular}{|c|c|c|c|c|c|c|c|}
\hline$T$ & 㠰 & $\overline{\text { 順 }}$ & & Tרת & スコア & (グラフ) & \\
\hline$\frac{1}{2}$ & 需 & 位 & レンシ & |スコץ & $-2-1$ & 1 & 2 \\
\hline & 直接(晤) & & & -0.650 & $\square$ & & \\
\hline 全 & 直数(明) & & & 0.432 & & 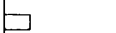 & \\
\hline 般 & 間接(暗) & $?$ & 2915 & 0.574 & & $\square$ & \\
\hline 照 & 間接(中) & 2 & 2.015 & 0.303 & & $\square$ & \\
\hline 明 & 間接(明) & & & 1.156 & & $\square$ & \\
\hline & tal & & & -1.159 & $\square$ & & \\
\hline 多㽞 & あり & & & 0.694 & & $\square$ & \\
\hline $\begin{array}{l}1 \\
1\end{array}$ & なし & 3 & 1.073 & -0.379 & 드 & & \\
\hline 多 & あり & 5 & 0.062 & 0.040 & & b & \\
\hline F & なし & & & -0.022 & & & \\
\hline 光 & 螢光 & 4 & 0347 & -0.266 & q & & \\
\hline 質 & 白熱 & 4 & 0.047 & 0.082 & & & \\
\hline 照 & $\sim 99$ & & & -1.824 & & & \\
\hline 度 & $\sim 199$ & 1 & 3.382 & -0.338 & 므 & & \\
\hline$T_{x}$ & $\sim 299$ & & & 0.970 & & $\square$ & \\
\hline & $300 \sim$ & & & 1.559 & & $\square$ & \\
\hline
\end{tabular}

図 1 外的基準 “明るい一暗い” の分析結果（相関 比: 0.990)

Fig. 1 The effect of illuminating components on emotion "well-lighted".

室内需囲気の実験を行った。

この研究でも，いろいろ多くの事柄が判明したが，特 定の室内イメージを創りだすには，どんな光源でどんな 照明方法で，照度をどれほどにすればよいかがわかった のである.乙れは後述する HULIS に活用されている.

\section{(5) その他の研究}

現在着手している研究としては，いわゆるタンスなど の箱物産業の復活のために，箱物の消費者から歓迎され るデザインとは何かの研究を進めている．とれについて は，木材の材質が人間に与える素材感に関する研究が終 了したところであり，てれから箱物のデザインや色彩に ついての研究に入る.

後述する HULIS の応用編として，女性の情緒分野に 進出し, 婦人服のデザインや色彩と, それから受けるイ メージの研究に入っており，てれもできるならば知識工 学的手法を使って，コンピュータを間にして顧客とデザ イナーが対話しながら好みのデザインを決定するインタ ーフェイスにしたいと考えている.

そのほか, ソファの研究の応用として乗用車のデザィ ン要素の情緒工学的研究を手がけたところであり, 情緒 性が重視される商品開発には無限といってよいほど，乙 の情緒工学が応用できると思われる.

\section{HULIS の開発}

\section{4-1． HULIS 開発の経緯}

HULIS とは Human Living System の省略文字であ り, HLS の拡張ソフトウェアのととである6 ${ }^{6}$.

前述したように，十数年前に情緒志向の生活様式に変 わることを予想して室内雾囲気の研究に入り, 主として 天井, 壁, 床の色彩が醸成するイメージの研究を行い, それを HLS と名づけて実用化した。これは室内装飾業 者のための商品化であるが, 顧客は住宅建設に関しては, 外観イメージから室内イメージにいたるまで，毎日の生 活が精神的に満足できるかどうかにかかっているのであ り，住宅をトータルにみた情緒工学的デザイン要素の決 定システムの開発が望ましいと考えたのである.したが って, HULIS では住宅の成分を外観, 外構, 玄関, 和 室, 洋室, 台所, 風呂の 7 つに分け, それぞれを 40 60 のデザイン要素に分解し、人間の複雑な情緒にできる だけ近つけるように工夫した。

2 番目の特徴は, 建築デザイナー 40 名を被験者とし てデータを構成したてとである．やはり住宅となると專 門的なデザイン構成が必要であり，それとイメージとの 関係をデータベースにもつてとのほうが, 素人である顧 客が漠然とイメージを表現するよりも明確なイメージが 得やすいからである.

3 番目の特徴は，とうした専門家の知識（ことではイ メーシ）をデータベースとして, 知識工学的にシステム を構成し，コンピュータと対話しながら推論機能により 人間に近いイメージを表示する能力をもたせたてとであ ろ.

てのように，HULIS は HLS とは比較にならないほ ぞ, 内容といい構成といい，実用範囲も含めて，格段に 進歩したソフトウェアである，てのシステムは，次に述 べる 3 つの主要な部分に分かれる。

\section{4-2. HULIS の構成}

\section{（1）形容詞処理部}

図 2 に HULIS のシステム構成を示す. HULIS で は，住宅を建てたい顧客が建築業者と対話しながら外 観, その他の成分に対して自分のもっている希望イメー シをコンピュータにインプットすると，コンピュータが それらのイメージを推論機構によりディスプレイに呈示 する. したがって, 住宅の基本構成の次の詳細設計に相 当する部分であり, 顧客の满足するデザインが完 成 す 


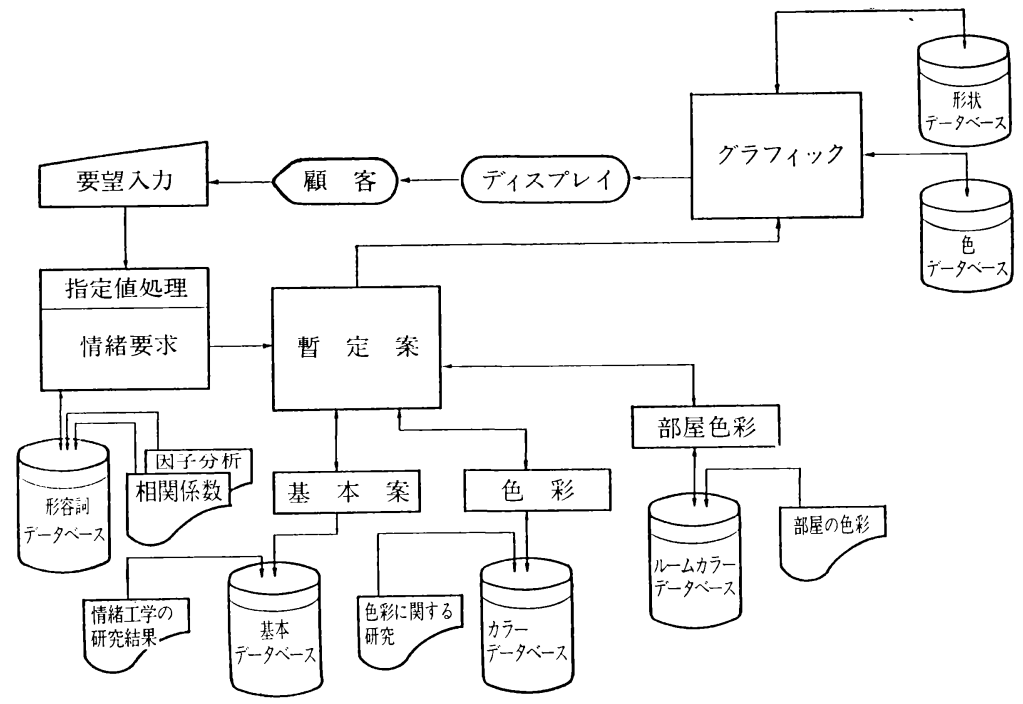

図 2 HULIS のシステムフロー図

Fig. 2 A diagram of HULIS system flow.

る.コンピュータは両者の間のイメージの交流をサポー トする働きをもつ。

このシステムでは，まず第一に顧客の話す形容詞が理 解できなければならない，そのために HLS の 500 対語 以外に顧客が話す言葉を記録して追加し、SD 法による 評価の手続きを経て， 227 対話を構成し形容詞データベ 一スとしている．ただし，そのうちの 40 語が基 本形容 詞であり，てれがイメージ変換の基本的なデータベース につながっている.

\section{(2) イメージ処理部}

イメージ処理部は, 前述の顧客の形容詞から具体的な デザィン要素に変換して映像を決定する機能である．乙 こは数量化理論 I 類で表したデータベース, 照明の情緒 工学的研究から得られた照明データベース, 色彩理論デ 一タベースなどの各種のデータベースを保持し，乙れら はプロダクションルームないし直接のデータで表示され ている．各種のデータベースが引きだされた場合に矛盾 しないように，黒板モデルが交通制御を行う.

（3）ゲラフィック表示部

HULIS の推論によってデザイン要素が決定される と,グラフィック表示部がそれに基づいて絵と色彩とを 表示する. あらかじめ 7 つ成分に関して, いく通りか のグラフィックが用意されており, スタイルと色彩とが 決定されて表示される. 1つの形容詞に関していくつか の絵がランク別に用意されていて, 抱いているイメージ を検索できるし，部分的にグラフィックの内容を変更す
るとともできる.

てうして, 顧客とインテリアデザイナーは HULIS を間にして互いのイメージの交流を行い，最終的に顧客 が満足する住宅デザインを決定するととができる。

\section{5. 心理学と情緒工学, そしてエ学}

情緒はもともと心理学的研究対象である. 古くはジェ イムスの情緒研究などがあるが，実用化という点では， 心理学的研究からは全く離れた存在であったと思われ る.ところが人間工学からみれば, マンーマシンシステ ムのなかに必ず “マン” が存在し，しかもその人間は物 理的存在ばかりでなく,精神的・心理的存在なのである.

与えられた手順なら学働者は嫌うが，自分が工夫した手 順なら学働者は快く働くとのように，人間工学では情 緒や感情を含めてマンーマシンシステムを考慮しなけれ ば成りたたない学問である，つまり，心理学がより機械 化されつつあるなかで, 人間工学はより人間化へ進まね ばならない性格をもっている。

情緒工学は心理学のひとつの応用であると同時に，人 間工学のより心理学的応用といえるし, 工学々心理学と を結びつける作用をするものである。

情緒的志向は今後もますます必要となるし，ての考え 方を適用できる分野はたくさん存在する，乙こに述べた 内容で情緒工学が完成したのではなくて,てれがての学 問の端緒にすぎない.今後とも，乙の新しい分野の研究 
者の仲間が増えることを期待したい．

\section{参考文献}

1）大島正光: 情緒工学一情緒と人間工学, 人間工学, 8(5), 207 213, 1972.

2）長町三生, 瀬沼 勲, 岩重律子 : 情緒工学 の研 究, 人間工学, $10(2), 121 \sim 130,1974$.

3）長町三生, 瀬沼 勲, 岩重律子：室の雲囲気に関 する感情分析, 人間工学, 13(1), 7 14, 1977 .
4）梁瀬度子：コーヒーカップのデザインの心理評価 に関する研究, 人間工学, $14(6), 327 \sim 334,1978$.

5）長町三生, 伊藤宏司, 福場良之, 辻 敏夫, 田判 義彦, 入枝輝昭: 室内照明の情緒工学的研究, 人間 工学, 21(5), 265 270, 1985.

6) 長町三生, 伊藤宏司, 福場良之, 辻 敏夫, 川本 浩史：知識工学手法によるインテリア・コンサルテ ーション・システムの開発, 人間工学, 22(1), 1 8, 1986. 